Northwestern University School of Law Northwestern University School of Law Scholarly Commons

Faculty Working Papers

2010

\title{
International Law from a Machiavellian Perspective
}

Anthony D'Amato

Northwestern University School of Law, a-damato@law.northwestern.edu

\section{Repository Citation}

D'Amato, Anthony, "International Law from a Machiavellian Perspective" (2010). Faculty Working Papers. Paper 92.

http://scholarlycommons.law.northwestern.edu/facultyworkingpapers/92 
International Law from a Machiavellian Perspective, by Anthony D'Amato, pp.82-95, in The Realist Tradition and Contemporary International Relations, ed. by W. David Clinton, (Political Traditions in Foreign Policy series), Louisiana State University Press, 2007

\begin{abstract}
Machiavelli leaves one with both an optimistic and a pessimistic prognostication for the post-Cold War world. On the one hand, the end of that conflict has opened the way for the spread of liberal, constitutional regimes, which he would say are inclined to be more and more meticulous in honoring their commitments. On the other, the temptation to use force to create new facts and thereby force international law into new paths will remain as long as politics is practiced. The contemporary relevance of Machiavelli may be seen in that he urged both realities upon us. I focus on a single incident that postdated the end of the Cold War-the show of force by the People's Republic of China (PRC) in the Taiwan Strait in March 1996.
\end{abstract}

Tags: Machiavelli, International Law, Two China Problem, Strait of Taiwan Show of Force (1996),

[pg82]* There are two kinds of combat: one with laws, the other with force. The first is proper to man, the second to beasts; but because the first is often not enough, one must have recourse to the second.

MACHIAVELLI, The Prince, XVIII

The purpose of this essay is to view international law in light of Machiavelli's teachings on politics. I focus on a single incident that postdated the end of the Cold War - the show of force by the People's Republic of China (PRC) in the Taiwan Strait in March 1996. The disadvantage of writing about events that have relatively recently transpired is that some relevant information is unavailable because it has not been made public. However, there is also an advantage: there is less danger of rationalization. For example, if ten years from now a scholar looking at state archive materials on the Taiwan Strait incident of1996 finds numerous memos on the international law aspects of the problem, the scholar may be led to believe that concerns about international law played a large role. Yet the paper trail may unduly magnify itself in historical contemplation; unrecorded conversations in soundproof rooms may have played a larger role in policy decisions. Machiavelli himself did not hesitate to use recent events interchangeably with historical materials to provide illustrations for his ideas.

Although he rarely discussed international law,FN1 Machiavelli's work illuminates the present-day study of international law because of what he had to say about power. One aspect of the complex relation between law and powerFN2 is that law can be an extension and implementation of a ruler's power. An autocratic prince will find that imposing law and order on his subjects simply increases his own wealth and freedom of action and hence is a useful tool in his arsenal of power. The law that he imposes upon his subjects does not apply to himself; he is free to disregard it. Similarly, [pg83] those who are skeptical about international law often say that powerful nations use international law to impose their will upon smaller nations, while disregarding that same law when it in their national interest to do so. The problem with this aspect of the relation between law and power is that it is simple and trivial and only applies, if at all, in extreme cases, when all the chips are down. Machiavelli, the realist, knew that, when the chips were down, an autocratic prince would use his power to trump whatever legal rules were in place. And indeed, bullets will always win over words; it is futile to expect law to restrain activities when all the chips are down. To kill someone in selfdefense who is about to murder you is regarded in all countries as an exception to the law 
against murder, not because the law says so (many early statutes making murder a criminal act did not mention self-defense) but because it would be futile for the law to attempt to restrain a person who must kill in order to avoid being killed. Machiavelli acknowledged that in a serious emergency it may be necessary to break the law. But breaking the law carries a price: "it establishes a custom of breaking laws for good purposes; later, with this example, they are broken for bad purposes."FN3

Although extreme cases are important, most of the time the cases are ordinary. Moreover, the more law there is, the fewer will be the occasions where cases are regarded as extreme. The more rules there are (or seem to be) in international relations, (1) the more states will interpret their own interests in light of those rules and (2) the more states will regard those rules as dispute-settlement mechanisms. As an example of (1), suppose that the international rule of freedom of the seas did not exist. Coastal states would then regard it as essential to their national interest to grab as much of the high seas as possible and militarily enforce it against predators from all the other nations. Instead, the rule of freedom of the seas simply removes from the active consciousness of government officials any desire to use power to engage in obtaining and securing sovereignty over the high seas. The rule simply removes an array of potential crises from consideration. As an example of (2), legal rules perform a natural function of being invoked by disputing parties in an effort to get their own positions accepted by the other side. If there is a set of relevant rules of international law out there to be invoked, governments will nearly always find it cheaper to invoke those rules in support of their own positions than to use military force; lawyers are cheaper than armies. Once lawyers from both sides get together to haggle over rules, crises tend to get defused, and a certain amount of giveand-take and minor accommodations begins to look [pg84] desirable to both sides. I am not talking here about international courts as dispute-resolving mechanisms, even though such courts naturally reinforce the perception that disputes can be resolved peacefully. International law works in the absence of courts in the hundreds of minor international disagreements that are the daily stuff of foreign offices and embassies, with which Machiavelli, having himself served as an envoy, was certainly familiar. And even in major disputes, the availability of an apparently neutral set of rules is an almost irresistible invitation to try to accomplish one's goals by invoking and citing those rules.

Both (1) and (2) work together to produce a kind of increasing momentum. The more international law is given credit for defusing tensions or serving as a reference point for the resolution of conflicts, the better it will accomplish both of these tasks in the future. Perhaps a better way to make this point is that law works as a long-term phenomenon. This is due to two main factors. First, law operates reciprocally: although state $\mathrm{S}$ may lose today to state $\mathrm{T}$ because of rule $\mathrm{X}, \mathrm{S}$ may win tomorrow against state $\mathrm{U}$ citing the same rule, and a year from now its position might change so that rule $\mathrm{X}$ now operates in S's favor against state $\mathrm{T}$. Second, the entire system of law may be perceived to work in a powerful state's favor over time, despite the fact that not all of its rules are welcome. For example, the United States has changed its position on the Law of the Sea Treaty. During the Reagan administration, the United States refused to sign the treaty because of just a few provisions in the treaty-those that relate to ocean floor mining. The Clinton administration, while still viewing those rules as distasteful, simply concluded that you can't win them all and that most of the provisions in the Law of the Sea Treaty were sufficiently valuable to the United States as to outweigh the costs associated 
with accepting the rules on deep sea mining. A contributing factor was the later assessment that the Reagan administration's evaluation of the potential profits of deep sea mining was overly optimistic. What is true of treaties is even truer of customary international law as a whole. If a powerful country flouts the system and acquires an outlaw status in the eyes of other countries, it risks losing more than it gains, especially since some of the risks are indeterminate (because customary law is itself to some extent indeterminate and continuously in the process of revision). Hence, over the longer term, the more powerful states begin to perceive that international law as a whole works in their self-interest. If international law did not exist today, I would be foolhardy in predicting that it would begin to arise tomorrow. But because it exists today, has existed for many centuries, and is becoming increasingly dense [pg85] and finemeshed, there is not much risk in predicting that it will be more effective and important tomorrow than it is today.

Even in Machiavelli's world where princes deposed other princes and mercenary armies conquered city-states and even turned against the princes who hired them,FN4 he advised founding princes to continue many of the old laws that people were accustomed to.FN5 Moreover, Machiavelli never said that princes were above the law; rather, they had the power to violate the law, but they often had to pay a price for doing so. He gave the example of Savonarola, who got a law passed and then did not observe it; his conduct "took influence away from him and brought him much censure," and added, "I do not think there is a thing that sets a worse example in a republic than to make a law and not keep it, and so much the more when it is not kept by him who has made it."FN6 International law is made by the statesFN7 and hence, to the extent that a powerful state has made a lot of it, that same state is perhaps all the more restrained from breaking the law for the reason that Machiavelli gave in his example of Savonarola.

The idea that law works best in the long run can be found in Machiavelli's observation about governments: "Governments by princes have lasted long, republican governments have lasted long, and both of them have needed to be regulated by the laws."FN8 This situation can obtain only when the prince himself obeys the laws: "when the people see that under no circumstances will he [the prince] break those laws, in a short time they feel secure and contented. An example is the kingdom of France, which lives safely for no other reason than that those kings are restrained by countless laws in which is included the security of all her people."FN9

Once a prince comes to realize that social control is a function of obeying the law, his mind may begin to rule out any base desires to break the law. He realizes, as Machiavelli implied, that the more he obeys the law the greater his personal power becomes. An orderly society that obeys the law is the ultimate portrait of the prince's personal power. Yet there seems to be a blind spot in Machiavelli's discussion of the Roman emperors: FN10 he does not perceive that some of them may have gotten high by arbitrarily violating the law. An emperor may lead the public to expect regularity through law, and then suddenly break the law himself in a situation that has absolutely no social utility-in fact, its consequences are deliberately harmful, and the shock and disbelief experienced by the public at the emperor's act is precisely what gives him his euphoric feeling of total power. It is possible that Saddam Hussein's decision to invade Kuwait in 1990 was this kind of deliberately shocking act driven by power- 
lust, for it is hard otherwise [pg86] to account for the folly of his decision. However, as we move away from princes and move toward republics - as nations are increasingly run by parliaments, groups, and committees - the chance of arbitrary breaches of international law may diminish. Individual power-lust can be filtered out in tedious committee meetings. In international law we are seeing occasional moves and feints toward war as if to remind one's antagonists that resorting to international force is not an entirely forgotten idea. Indeed, tweaking the rules of international law can sometimes be an advantage in international power confrontations, as we will see in considering the events of March 1996 off the China coast.

The United States in 1996 was the number one military power in the world; by most estimations, China was number two. Although Taiwan had considerable defense capability, it was not a formidable military power. Yet Taiwan was a strong economic trading partner with the United States (and with the People's Republic of China [PRC]), and had a democratic government that the United States had an interest in preserving. Although the States in 1979 had terminated its Mutual Defense TreatyFN11 with Taiwan and had gradually withdrawn its soldiers who were stationed on that island, it continued its policy of arms transfers to Taiwan. Perhaps U.S. military strategists perceived that arming Taiwanese was more effective in discouraging aggressive impulses by the PRC than leaving U.S. troops on the island as a tripwire. After all, a future U.S. administration might withdraw the troops; perhaps, even in the course of a Chinese invasion, the American public would not tolerate the loss of American soldiers defending the Taiwanese, and would want them brought home. Moreover, military selfdefense has a huge battlefield advantage. If the PRC were to send fleets of soldiers across the Taiwan Strait, under standard military theory it would need at least twenty attacking personnel for every Taiwanese defender. In addition, the preparations for any such attack from the mainland would be visible months in advance, giving the United States and other countries ample opportunity to come to the rescue of Taiwan. The 1992 sale to Taiwan of 150 F-16 advanced jet fighters was dramatic corroboration of this aspect of U.S. policy. The PRC repeatedly and bitterly denounced U.S. arms transfers to Taiwan, but could do nothing about them.

By February 13, 1996, there were some Chinese military maneuvers from inland toward the Chinese coast opposite Taiwan. At a White House press briefing, the following exchange took place: [pg87]

Q: Has China been given an ambiguous answer on what we would do if it did attack Taiwan?

PRESS SECRETARY MIKE MCCURRY: Oh, I doubt very much, given the PRC's understanding of the Taiwan Relations Act, FN12 that they have much doubt.

Q: I thought you said earlier that we were being deliberately ambiguous.

MR. MCCURRY: Well, we've not—we've never specified the exact response consistent with the exact wording of the Taiwan Relations Act. But if you look at that act, if you look at the requirement for peaceful resolution of issues related to the Straits, it's quite clear what the view of the international community would be of any unnecessary provocation. 
Q: What would that be?

MR. MCCURRY: It's very clearly specified in the Taiwan Relations Act.

Q: Which is?

MR. MCCURRY: Which I don't have in front of me.FN13

One may note a theoretical equivalence between a government spokesperson's statements "our policy is ambiguous" and "our policy is clear but I don't know what it is." The important point is that the United States was not willing to reveal any of its military contingency plans in advance of China's intentions becoming clearer; the rest is the usual diplomatic double-talk.

A month later, the U.S. government, through its spokesperson, opted in favor of directly labeling its policy as ambiguous:

Q: Do you think the United States would be bound by the 1979 Act to defend Taiwan against Chinese aggression?

MR. MCCURRY: The 1979 Taiwan Relations Act does not answer that question specifically and, indeed, there is merit we believe in keeping somewhat ambiguous about the matter.FN14

Various motives have been ascribed to the PRC for amassing its military forces in the Taiwan Straits. The American media reported that China was trying to influence the upcoming Taiwanese presidential elections on March 25, and that China was concerned about the example on the Chinese people of Taiwan's open and democratic elections. Neither of these alleged motives is particularly credible. It seems instead that China was making a statement during the Taiwan election campaign that no matter who was elected, the government should cease its foreign activities seeking [pg88] to obtain an international personality for Taiwan. I cite as evidence for this proposition a report by CNN on March 12 that the PRC offered to withdraw its military forces from the Taiwan Strait if Taiwan withdrew its overseas campaign for entry into the United Nations - an offer that Taiwan promptly rejected.FN15

By March 5, the PRC had announced that it was going to conduct war games, including missile exercises in the Taiwan Straits. The U.S. reaction, given at a White House press briefing, was restrained:

MR. MCCURRY: We have long felt that military exercises of that nature, specifically these types of missile tests, don't do anything to contribute to peace and stability in the region.FN16

Two days later, the press secretary (1) refrained from admitting that there had been tests and (2) that the PRC had announced missile tests, and (3) characterized them in more forceful language:

MR. MCCURRY: If, indeed, there have been missile tests associated with military exercises that are underway now adjacent to the Taiwan Straits, they would be consistent with what the 
People's Republic had previously announced. They've previously announced they would likely include as part of this exercise missile tests. We would be deeply disturbed by any test of that nature, consider that provocative, and consider them reckless.FN17

The United States was speaking from a position of having monitored the Chinese troop movements. It came to the conclusion that the deployment of force in the Taiwan Strait did not have the characteristics of a preparation for invasion of Taiwan. Thus there was practically no chance that China intended to start a war with Taiwan. Moreover, intentional aggression against Taiwan would be irrational from the Chinese perspective (although, with Saddam Hussein's invasion of Kuwait freshly in mind, one should never rule out the capacity of dictatorial leaders to commence a wholly irrational war). A war against Taiwan would be irrational, first, because several thousand American citizens were present in Taiwan (a number of them working in the quasi-diplomatic American Institute in Taiwan set up by the Taiwan Relations Act). Chinese aggression against Taiwan would undoubtedly trigger a huge American military response if for no other reason than to protect the lives of American citizens on Taiwan. Second, China continued to count on the support of many Taiwanese residents who were loyal to the PRC. An invasion that would be [pg89] preceded by artillery and missile fire would not be able to distinguish between these compatriots and other Taiwanese citizens, and thus would endanger everyone. In recognition of this problem, Foreign Ministry spokesperson Shen Guofang was quoted on Chinese state radio as saying. "China has never promised to give up the use of force, though of course this is not directed at the Taiwan compatriots."FN18 How can artillery and missile fire spare those compatriots in crowded proximity with other Taiwanese citizens? War is simply too blunt an instrument these days compared with the city-states of Machiavelli's time. Bombarding Taiwan would have the effect of immediately turning the compatriots against China. Finally, Taiwan had a substantial defense capability. Despite China's overwhelming troop strength (over 3 million soldiers), its meager amphibious capability would give Taiwan's beach perimeter defense an almost insuperable advantage.

Yet military hostilities can arise from mistakes and accidents, which is probably one reason Secretary McCurry used the words provocative and reckless. In the war of words that was going on, the PRC responded within five days that the U.S. policy was "stupid and reckless."FN19 I will now try to show that the fear of error escalating into war was the linchpin in the confrontation between the PRC and the United States in March 1996.

The Chinese war games in the Taiwan Strait began on March 11. More than 150,000 Chinese troops were involved in the live ammunition exercise, as were a flotilla of ships and at least three hundred airplanes.FN20 The United States responded by deploying significant naval forces to international waters several hundred miles east and southeast of Taiwan, and not in the Taiwan Strait. Included was the USS Independence, a carrier group out of Yokosuka, Japan, that included several cruisers, destroyers, frigates, and nuclear attack submarines. A second carrier group, the USS Nimitz was sent from the Persian Gulf to international waters southeast of Taiwan.F21 The U.S. Navy did not conduct live ammunition war games, but engaged in noticeable twenty-four-hour-a-day exercises, including eighty sorties daily from the USS Independence. 
Rear Admiral James Ellis, commander of the Seventh Fleet Battle Force, told CNN news: "What is our purpose here, and it is not to bully or intimidate. We are here to monitor the ongoing military exercises. The Chinese themselves have said that's a normal naval function. That's what they do with us, that's what we do with them.”FN22 It is a classic case of creating an ambiguity between words and actions. The United States did not need two huge carrier fleets to "monitor" the Chinese games; that was [pg90] already being done by reconnaissance satellites, and in any event the fleets were too far away to see or hear anything with the games. However, the PRC, for its part, understood full well that the United States was downplaying its naval presence near Taiwan, and rather than contradicting the U.S. characterization, instead chose to downplay it even further. Foreign Minister Qian Qichen was asked by a reporter on Beijing television to react to the American plans to move its carrier forces close to Taiwan. The minister replied, "It is common for U.S. warships to engage in activities in high seas."FN23 Earlier, in January 1996, Defense Minister Chiang Chung-ling had downplayed the matter perhaps to lowest possible level of discourse. Commenting on a rumor about a planned carrier traversal of the Taiwan Strait during the Taiwan elections in March, the minister said that he had not heard anything about it: "A minister will not necessarily know every trifling matter such as this. He is in charge of major affairs."FN24

In order to analyze these military and diplomatic posturings fully, they must be seen as interacting with rules of customary international law. One of those rules is that because the Taiwan is approximately 100 miles wide (and 137 miles long), it is an international waterway. Therefore, it is legally open to vessels of all nations. The Chinese military exercises effectively cut off that waterway, thus temporarily violating international law. Yet I believe it was part of the deliberate Chinese military strategy to violate international law. When any nation uses its military forces in violation of international legal norms, the intimidation factor increases. The target of the intimidation-namely, the Taiwanese people-would be uncertain whether the PRC might proceed to violate other international norms, such as the norm against aggression.

But this violation of international waters also presented a legal and military challenge to the United States. In December 1995 the USS Nimitz had traversed the Taiwan Strait. Would the U.S. Navy try it again in March 1996, when China was conducting live ammunition and missile tests in those waters? To do so would be to present a frontal challenge to the PRC: either back down, or continue the tests with the high probability of hitting the USS Independence and setting off a war with the United States. Prior to the tests China had issued a warning to international shipping and aviation to stay away from the Taiwan Strait. The PRC chose its language carefully on March 17, when it was still doubtful whether the U.S. Navy would try to navigate the Taiwan Strait. Prime Minister Li Peng said: "If someone makes a show of force in the Taiwan Strait, that not only be a futile [pg91] act, but it will also make the situation all the more complicated."FN25 The U.S. response was to play down the situation. A "White House official" said in Washington: "Although we don't like the newly announced military exercise, we take note of the fact that there is little to no interference with international shipping or air travel, that they take place far from Taiwan proper so that there is no direct threat, and that the Chinese have been careful in their rhetoric not to issue direct threats."FN26 In fact, the United States did not try to navigate the Taiwan Strait, and China brought its war games to an end two days after the presidential election on Taiwan. The entire affair ended peacefully. 
Allow me to speculate on the reasons behind the U.S. decision not to send either or both of its carrier fleets through the Taiwan Strait. First, though the United States branded the Chinese war games as "reckless," it had conducted and undoubtedly will continue to conduct similar naval war games of its own, especially in the Persian Gulf and in the Mediterranean (in order to intimidate states like Iraq, Iran, and Libya.) Any objection to the Chinese war games could come back to haunt the United States the next time it wishes to conduct similar exercises.

Second, the United States set the precedent for cordoning off a portion of the high seas when it conducted its nuclear tests in the South Pacific in 1954. At that time it notified international shipping and aviation to stay away from the specified area. However, the magnitude of one of the test explosions was underestimated by half, and there was in addition an erroneous wind prediction. A Japanese fishing vessel, which apparently lay fourteen miles clear of the warning zone, was caught in the radiation; its twenty-seven-man crew suffered serious injuries, one of them dying. The United States paid Japan \$2 million for the injuries to the crewmen and the damage to the Japanese fishing industry.FN27 Japan explicitly refused to demand that the United States discontinue its tests.FN28

These facts appear to establish that when the international legal norm of freedom of the seas is temporarily violated for the purpose of conducting weapons tests, the norm should be interpreted as a 'liability' rather than a "property" norm.FN29 Under this interpretation, if the USS Independence were to have entered the proclaimed war games zone in the Taiwan Strait) and if it had been hit by Chinese artillery fire or a missile, China could restored the situation to the status quo ante by promptly offering to pay full damages to the United However, this legal result would have been extraordinarily difficult for President Clinton to explain to the American people. There would have been cries in Congress to [pg92] retaliate with full force against China and the president would have been criticized as a weakling for accepting payment from China for the affront to the U.S. Navy. Thus, assuming that lawyers for the Pentagon and the State Department reasoned the matter through to this point, they might very well have advised the president that it was politically a no-win situation to send an carrier force through the Taiwan Strait.

The preceding two reasons have to do with the relation between rules of customary international law and military strategy. A third reason bears on the relation between political prediction and military strategy. White House political advisers may have come to the conclusion that the PRC made a political miscalculation in deciding to conduct military exercises in the Taiwan Strait. The PRC may have acted out of a sense of frustration that Taiwan was gradually heading toward independence from the mainland; not knowing exactly what to do about it, China may have simply decided to flex its military muscles-a decision that may have had more to do with the fact that the leadership was aging and nearly senile than with any sound political calculation.

But the predictable consequences of a military show of force in the Taiwan Strait would be to drive the Chinese compatriots on Taiwan closer to the rest of the Taiwanese citizenry, for reasons I have suggested earlier in this essay. Hence it would not be surprising to see in the months that followed an acceleration in the overseas activities of Taiwanese officials in the 
direction of independent statehood for Taiwan, stimulated by the Chinese demonstration in the Taiwan Strait in March 1996 (as, indeed, there has been in the years since 1996). If the White House made a similar assessment, then its best strategy would have been to bring the USS Nimitz and the Independence into the area—so as to show support for the people on Taiwanand at the same time let China go ahead with its war games with only mild remonstrance from the White House press secretary. If I am correct about White House strategy, it would simply be the latest example of an ambiguous and hence remarkably flexible policy that served the United States well through the years in preserving peace in the region of the Taiwan Strait and allowing the Two China Problem to work itself out at its own pace. In reading Machiavelli, one finds numerous examples of political miscalculation by princes and other rulers. One can be impressed by the subtlety and skill of Chinese diplomats and government spokespersons in the incident of the Taiwan Strait, and yet come to the conclusion that they may have simply been putting the best possible face on a mental decision that was ill-conceived and counterproductive.

[pg93] Nevertheless, Machiavelli would appreciate the uses to which China could put its perceived willingness to challenge international law in pursuit of political advantage. To be feared by the Taiwanese government could carry more benefits than to be loved even by the PRC compatriots in Taiwan. And to induce a certain caution in the actions of the world's premier superpower demonstrated leverage that Beijing might find useful in some future confrontation.

Moreover, an act of (even symbolic) force that contravenes international law mayparticularly if it is repeated — create a new state of affairs to which international law eventually will accommodate itself. Machiavelli recognized that an "external cause," such as a military defeat, may bring about "necessary change" in the laws of a state, a process that he distinguished from change brought about "by its own intrinsic good sense.”FN30 International law may be even more subject to alteration not through appeals to reason but through the creation of a new status quo by means of power. Machiavelli did not advocate the use of force to establish an altered power relationship "for though [external force] be the best remedy [for the degeneration of laws] it is so dangerous that in no case is it what one should desire."FN3l Still, when corruption has set in (and China has indicated that certain aspects of international1aw, such as the "unequal treaties" imposed on it in the nineteenth century, are tainted with injustice or corruption), "normal methods will not suffice ... Hence it is necessary to resort to extraordinary methods, such as the use of force and an appeal to arms."FN32 Frequent renovations are beneficial if they lead institutions "back to their start"- that is, back to their initial uncorrupted state. If removing any international legal barrier to China's ability to act as it pleased in the straits between the mainland and its "province" was viewed in Beijing as a cleansing of corrupt institutions and if "men never do good unless necessity drives them to it," then China's leaders could have reasoned in a Machiavellian way if they determined to risk the hazardous use of force.FN33

Machiavelli leaves one, then, with both an optimistic and a pessimistic prognostication for the post-Cold War world. On the one hand, the end of that conflict has opened the way for the spread of liberal, constitutional regimes, which he would say are inclined to be more 
and more meticulous in honoring their commitments.FN34 On the other, the temptation to use force to create new facts and thereby force international law into new paths will remain as long as politics is practiced. The contemporary relevance of Machiavelli may be seen in that he urged both realities upon us.

\section{FOOTNOTES}

*Numbers in the format "pg82” etc. refer to the pagination of the original publication.

FN l. He discussed Rome's violation of the law of nations in Discourses, II.28.

FN2 For an earlier essay discussing triangular relationships in Machiavelli's concept of power, see Anthony D'Amato, “The Relevance of Machiavelli to Contemporary World Politics”, in The Political Calculus: Essays on Machiavelli's Philosophy, ed. Anthony Parel (Toronto; University of Toronto Press, 1972), p. 209.

FN3 Discourses, I.34

FN4 Niccolo Machiavelli, The Prince, XII.18: “a leader having his state built on mercenary armies will never be secure."

FN 5. Discourses, I.9.

FN6. Ibid., I.45.

FN7. Customary international law is derived from the accommodations states work out in claim-conflict situations. International law as a whole is an extrapolation from state behaviorwhat other states do, and how they react to what other states do.

FN8 Discourses, I.58.

FN9. Ibid., I.16.

FN10. The Prince, XIX.190-300.

FN11. Mutual Defense Treaty, December 2, 1954, United States-Republic of China [Taiwan] 6 U.S.T 433, TIAS No. 3178.

FN12. 93 Stat. 14 (1979), 22 U.S.C. § 3301.

FN13. Press briefing by Mike McCurry, 1996 WL 60961 (White House, February 13, 1996).

FN14. Press briefing by Mike McCurry, 1996 WL 107147 (White House, March 12, 1996). 
FN15. CNN News Report, 6:03 p.m. ET, March 12, 1996. Later, on March 26, 1996 Foreign Minister Qian Qichen denied that the war games were an attempt either to influence the presidential campaign or to discourage democracy in Taiwan: "What we oppose are the separatist activities on Taiwan, and the forces working for Taiwan independence" ("Tensions Seen as Receding as China Ends War Games,” New York Times, March 26, 1996, p.8, col.4).

FN16. Press briefing by Mike McCurry, 1996 WL93855 (White House, March 5, 1996)

FN17. Press briefing by Mike McCurry, 1996 WL 99450 (White House, March 7, 1996)

FN18. CNN World News, 11:20 a.m. EST, March 1996.

FN19. Hong Kong newspaper Wen Wei Po, quoting Foreign Minister Qian Qichen, BBC Summary of World Broadcasts, EE/D2559/F, March 12, 1996.

FN20. CNN News, 6:03 p.m. ET, March 12, 1996.

FN21. CNN Worldwide Web, posted at 7:10 a.m. EST, March 13, 1996

FN22. CNN News, 10:31 p.m. ET, March 16, 1996.

FN23. BBC Summary of World Broadcasts, EE/D2558/G, March 11, 1996.

FN24. BBC Summary of World Broadcasts, EF/D2520/F, January 26, 1996.

FN25. "China Warns U.S. to Keep Away from Taiwan Strait,” New York Times, March 18, 1996, p.3.

FN26. Ibid.

FN27. New York Times, January 5, 1955, p. 6.

FN28. New York Times, April 2, 1954, p. 4.

FN29. See Guido Calabresi and A. Douglas Melamed, "Property Rules, Liability Rules, and Inalienability: One View of the Cathedral,” Harvard Law Review 85 (1972): 1089, explaining property rules and liability rules.

FN30. Discourses, III.1:3.

FN31. Ibid., I.10.

FN32. Ibid., I.18.5.

FN33. Ibid., III.l.1; I.3.2. 
FN34. Ibid., I.59.

\section{SUGGESTED READINGS}

D’Amato, Anthony. International Law and Political Reality: Collected Papers. The Hague: Kluwer Law International, 1995.

Fischer, Markus. "Machiavelli’s Theory of Foreign Politics." In Roots of Realism, edited by Benjamin Frankel. Portland, Ore.: Frank Cass, 1996.

Gilbert, Felix. "Machiavelli: The Renaissance of the Art of War." In Makers of Modern Strategy from Machiavelli to the Nuclear Age, edited by Peter Paret. Princeton: Princeton University Press, 1986.

Hulliung, Mark. Citizen Machiavelli. Princeton: Princeton University Press. 1983.

Machiavelli, Niccolo. The Discourses. Edited by Bernard Crick. Harmondsworth: Penguin, 1970.

The Prince. Edited by Quentin Skinner and Russell Price. Cambridge: Cambridge University Press, 1988.

McCanles, Michael, “Machiavelli and the Paradoxes of Deterrence.” Diacritics 14 (1984): 1219.

Morganthau, Hans. La Realite des Normes; en particulier des Normes du Droit International. Paris, 1934.

Parel, Anthony, ed. The Political Calculus: Essays on Machiavelli's Philosophy. Toronto: University of Toronto Press, 1972.

Skinner, Quentin. Machiavelli. New York: Hill and Wang, 1981.

Wight, Martin. Four Seminal Thinkers in International Theory: Machiavelli, Grotius, Kant, and Mazzini. New York: Oxford University Press, 2005. 